\title{
Effect of Different Level of Potassium on the Yield of White Jute (Corchorus capsularis L.) Fibre in Coastal Region of Bangladesh
}

\author{
Tazbin Piya ${ }^{1}$, Md. Tariqul Islam ${ }^{1, ~ *, ~ M d . ~ R a s a l-M o n i r ~}{ }^{2}$, Mahamuda Akter ${ }^{1}$, Md. Muzahidul Islam ${ }^{3}$ \\ ${ }^{1}$ Department of Agronomy, Patuakhali Science and Technology University, Dumki, Patuakhali, Bangladesh \\ ${ }^{2}$ Department of Horticulture, Sher-e-Bangla Agricultural University, Dhaka, Bangladesh \\ ${ }^{3}$ Department of Soil Science, Patuakhali Science and Technology University, Dumki, Patuakhali, Bangladesh
}

Email address:

sajibtariqul@gamil.com (Md. T. Islam)

${ }^{*}$ Corresponding author

\section{To cite this article:}

Tazbin Piya, Md. Tariqul Islam, Md. Rasal-Monir, Mahamuda Akter, Md. Muzahidul Islam. Effect of Different Level of Potassium on the Yield of White Jute (Corchorus capsularis L.) Fibre in Coastal Region of Bangladesh. Plant. Vol. 7, No. 4, 2019, pp. 66-70. doi: 10.11648/j.plant.20190704.12

Received: August 15, 2019; Accepted: August 29, 2019; Published: September 16, 2019

\begin{abstract}
To examine the effect of variety and different level of potassium (K) on yield of jute, an experiment was conducted at the Agronomy Field Laboratory, Patuakhali Science and Technology University, Dumki, Patuakhali from May to September 2016 using three variety viz. C-2197, C-3069 and C-3473. There are four levels of K viz. 0, 35, 45 and $55 \mathrm{~kg} \mathrm{ha}^{-1}$. The land was fertilized as per treatment specifications from muriate of potash along with recommended doses of urea, TSP, gypsum and zinc sulphate. The experiment was laid out in randomized complete block design (RCBD) with three replications. The variety O-3069 had significant influence on number of internodes per plant (64.20), plant diameter (21.15mm), fiber weight per plant $(25.92 \mathrm{~g})$, fiber yield $\left(5.18 \mathrm{t} \mathrm{ha}^{-1}\right)$, stick weight per plant $(64.75 \mathrm{~g})$ and stick yield $\left(12.94 \mathrm{tha}^{-1}\right)$. The highest results of plant height $(3.81 \mathrm{~m})$ and green weight with leaf $(4.04 \mathrm{~kg} / 10$ plant $)$ were obtain from C-3473 and green weight without leaf ( $3.54 \mathrm{~kg} / 10$ plant) were obtained from C-2197. Among the different potassium levels $55 \mathrm{~kg} \mathrm{~K}^{-1} \mathrm{had}^{-1}$ hignificant influence on number of internodes per plant $(70.13)$, plant diameter $(22.60 \mathrm{~mm})$, green weight with leaves $(4.43 \mathrm{~kg} / 10 \mathrm{plant})$ and green weight without leaves $\left(3.91 \mathrm{~kg} / 10\right.$ plant), fiber weight per plant $(27.93 \mathrm{~g})$, fiber yield $\left(5.59 \mathrm{t} \mathrm{ha}^{-1}\right)$, stick weight per plant $(69.60 \mathrm{~g})$ and stick yield $\left(13.90 \mathrm{t} \mathrm{ha}^{-1}\right)$. The highest plant height $(4.13 \mathrm{~m})$ were obtained from $35 \mathrm{~kg} \mathrm{~K} \mathrm{ha}^{-1}$. The variety O3069 with $55 \mathrm{~kg} \mathrm{~K} \mathrm{ha}^{-1}$ had significant influence on plant diameter $(24.00 \mathrm{~mm})$, fiber weight per plant $(31 \mathrm{~g})$, fiber yield $\left(6.2 \mathrm{t} \mathrm{th}^{-}\right.$ $\left.{ }^{1}\right)$, stick weight per plant $(77.53 \mathrm{~g})$ and stick yield $\left(15.50 \mathrm{tha}^{-1}\right)$. The highest results of plant height $(4.30 \mathrm{~m})$, number of internodes per plant (73), green weight with leaf $(4.85 \mathrm{~kg} / 10$ plant) and green weight without leaf $(4.25 \mathrm{~kg} / 10$ plant were obtain from C-3473 with $55 \mathrm{~kg} \mathrm{~K} \mathrm{ha}^{-1}$. The results of the present experiment showed that the C-3069 was the best among the varieties. On the other hand, $55 \mathrm{~kg} \mathrm{k} \mathrm{ha}^{-1}$ was proved to be better than any other lower and higher levels of potassium. Therefore, it can be inferred that jute can produce the highest fibre yield from a combination of variety C-3069 with $55 \mathrm{~kg} \mathrm{k} \mathrm{ha}^{-1}$ in field under the coastal region of Bangladesh.
\end{abstract}

Keywords: Potassium, Variety, Fiber, Yield

\section{Introduction}

Jute (Corchorus capsularis) is an important foreign exchange earning commercial golden fibre crop of Bangladesh. Jute is the second important fibre crop of the world and it is generally known as golden fibre of Bangladesh as it contributed as lion share to the economy. It is grown in Bangladesh, India, Myanmar, Nepal, China, Taiwan, Thailand, Vietnam, Cambodia, Brazil and some other countries. In Bangladesh, the area of Jute cultivation is $7,08,723$ hectares of land where the total production is 83 , 95,840 bales per annum with an average yield of 4.79 bales per acre (11.846 bales per hectare) which was found by the statistical report of 2010-11 [2]. The area under jute 
cultivation has increased approximately $15.84 \%$ during 2012 2013 (680000 ha) in comparison to 2010-2011 (587000 ha). In 2012-13, Bangladesh produced 7.51 million bales of jute, which was immediately after India (9.22 million bales). But, regret is that total jute production has declined by about $3 \%$ in 2012-2013 (7.51 million bales) than 2010-2011 (7.73 million bales). On the other hand, yield per hectare has also decreased from $2.39 \mathrm{t} \mathrm{ha}^{-1}$ in $2010-2011$ to $2.00 \mathrm{t} \mathrm{ha}^{-1}$ in 2012-2013. [7].

Once jute was known as the golden fibre of Bangladesh, since it was the most important cash crop of the country. Jute fibre is produced mainly from two commercially important species, which have two particular economic and culinary value Chorchorus olitorious (Tossa Jute) and Chorchorus capsularis (Deshi Jute). Jute contributes significantly to the economy of Bangladesh, as it is the major source of foreign currency by exporting jute fibre and goods produced from it [4]. Moreover, the crops itself improves the soil fertility and its sticks are indispensable to the farmer for fuel, fencing and thatching.

Jute is extensively used throughout the world because of its versatility, durability, and fineness. Its fibre is mainly used in manufacturing various types of industrial products such as hessian, sacking, carpet backing, cloths, mats, blankets, fabrics, packing materials, etc. Bangladesh earns about $6-7 \%$ foreign exchange through exporting raw jute and jute goods [3]. The fibre is also used to prepare ropes and housing materials for domestic uses. Jute sticks are used as fuel and fence. In recent years, the green jute plants are being used as raw materials for paper pulp in the paper mills. Jute is also used for partex and jute geo-textile [9]. The area and production of jute are declining day by day but horizontal expansion of area under this crop is not possible so, vertical expansion is the only way to increase the jute production. If we can increase the production of jute we can export thousand tons of jute in other countries. Increased yield with quality fibre and strong stick with additive nutritional constituents in jute is highly desirable to be grown that would permit more expansion of jute cultivation in our country.

Development of improved crop varieties including hybrids with high yielding potential and judicious application of fertilizer are some of the best option available to the agriculturist in order to break through the present yield ceiling of the modern varieties and to expedite a sustainable increase in jute production. Variety is one of the effective factor for raising such production is another important way to increase the jute yield. Appropriate nutrient management strategy is another most important way to raise the yield of jute. Potassium $(\mathrm{K})$ is one of the primary as well as the third so called major food element for plant growth and development. $\mathrm{K}$ controls the diseases of jute as well as increase the quality and strength of jute fibre. $\mathrm{K}$ also increases the yield. The time of application of $\mathrm{K}$ is another important aspect of jute production.

\section{Methodology}

\subsection{Plant Materials}

The seeds of jute (Corchorus capsularis) were used as the planting material in the experiment. Seeds were collected from the Bangladesh Jute Research Institute (BJRI), Khepupara, Patuakhali. Seeds were tested for germination before sowing and it was found $95 \%$ germination.

\subsection{Experimental Design and Layout}

The experimental plot was laid out in a randomized complete block design (RCBD) with three replications. The number of plots in the experiment was 36 . The size of individual plot was $2.0 \mathrm{~m} \times 3.0 \mathrm{~m}$. There are three jute variety viz., C-3473, C-3069 and C-2197 and 4 treatments i.e. $0 \mathrm{~kg} / \mathrm{ha}, 35 \mathrm{~kg} / \mathrm{ha}, 45 \mathrm{~kg} / \mathrm{ha}, 55 \mathrm{~kg} / \mathrm{ha}$ potassium $(\mathrm{K})$ along with a control will be distributed randomly in each plot as one replication.

\subsection{Land Preparation and Application of Fertilizers}

The experimental land was first opened on May 5, 2016 with a power tiller. Thereafter, the land was ploughed and cross-ploughed to obtain good tilth. Laddering was done in order to break the soil clods into small pieces followed by each ploughing. The calculated entire amount of all fertilizers was applied during final plot preparation. The applied fertilizers were mixed properly with the soil in the plot. The whole amount of TSP, Gypsum and $1 / 2$ of Urea were applied as basal dose at the time of final land preparation. The remaining $1 / 2$ of the urea was top dressed in splits at 45 days after sowing. Muriate of potash was used as per treatment.

\subsection{Seed Sowing}

The collected seeds of Jute were broad sown at May 12, $2016 @ 20$ g $^{2} \operatorname{lot}^{-1}$ of each cultivar, respectively for getting proper population in the plot.

\subsection{Harvesting}

The crop was harvested on 22 September, 2016 when the crop reached at 50\% flowering stage. Before harvesting 10 sample plants were taken at random from each plot to study the yield contributing characters of jute. After harvesting the jute plants were made into small bundles and kept standing on the ground for 4 days for shedding of leaves prior to steeping.

\subsection{Retting, Stripping, Washing and Drying of Jute}

After shedding of the leaves, the jute bundles were steeped plot-wise on 25 September in pond water for retting. The retting was completed within 20 days after steeping. In the retting process the fibres in the bark get loosened and separated from the woody stalk due to the removal of pectines, gums and other mucilaginous substances. This is usually caused by the combined action of water temperature and microorganisms. After proper retting, the fibres were extracted by stripping and were washed thoroughly in water. 
The extracted fibres were dried in the sun plot-wise on bamboo bars. After drying, the fibres were weighed to get the fibre yield. After stripping, the jute sticks were dried in sun by keeping them standing against bamboo bars. The sun dried sticks were weighed to record the yield of sticks. Retting, washing and drying of the sample plants were also done in the similar way.

\subsection{Statistical Analysis of the Data}

The recorded data were compiled and tabulated for statistical analysis. Analysis of variance was done with the help of computer package of MSTAT-C. The differences among the treatment means were adjudged by Duncan's Multiple Range Test (Gomez and Gomez, 1984).

\section{Results and Discussion}

\subsection{Plant Height}

The analysis of variance for plant height of different varieties of the experiment showed significant variation. From Table 1 it is obvious that highest plant height $(3.88 \mathrm{~m})$ was recorded from C-3473. The shortest plant height $(3.76 \mathrm{~m})$ was in C-2197. Variation in plant height might be due to the difference in their genetic make-up [13]. The effect of potassium level on plant height showed significant variation among varieties. Plant height was found the highest $(4.13 \mathrm{~m})$ at $35 \mathrm{~kg} \mathrm{~K} \mathrm{ha}^{-1}$, second highest plant height $(4.09 \mathrm{~m})$ was recorded from treatment $\mathrm{K}_{55}$ and lowest plant height $(3.27 \mathrm{~m})$ was recorded from treatment $\mathrm{K}_{0}$ (Table 2). The present study is also in agreement with the findings of $[11,5,14,6,12]$. The combination between variety and different levels of $\mathrm{K}$ on plant height varied significantly (Table 3 ). The highest plant height $(4.30 \mathrm{~m})$ was recorded from $\mathrm{V}_{1} \mathrm{~K}_{55}$ treatment combination. The lowest plant height $(3.24 \mathrm{~m})$ was recorded in variety $\mathrm{C}-3473\left(\mathrm{~V}_{1} \mathrm{~K}_{0}\right)$ when there was no application $\mathrm{K}$ fertilizer.

\subsection{Number of Internodes Per Plant}

There was significant variation found among varieties regarding of number of internodes per plant. Variety C-3069 produced highest numbers of internodes (64.20) per plant, which was statistically similar to C-3473 (63.90). The lowest number of internodes (62.80) was counted from the variety C-2197 (Table 1). Potassium application influenced number of internodes per plant positively i.e. with the application of $\mathrm{K}$ fertilizer number of internodes per plant increased. The highest number of internodes per plant (70.13) was counted at $55 \mathrm{~kg} \mathrm{~K} \mathrm{ha}{ }^{-1}$, (Table 2) and the lowest number of internodes (55.43) was found at $\mathrm{K}_{0}$ (without $\mathrm{K}$ ) treatment, though there was no significant difference with the treatments viz. $K_{35}(68.47)$ and significant difference with the treatments viz. $\mathrm{K}_{45}(60.50)$. Interaction effect of variety and different levels of $\mathrm{K}$ on number of internodes per plant was found significant (Table 3). From Table 3 the highest number of internodes per plant (73) was recorded in $\mathrm{C}-3473$ at $\mathrm{K}_{55}$. The lowest number of internodes per plant (54.73) was counted from the combination $\mathrm{C}-3473 \times \mathrm{K}_{0}$ (without $\mathrm{K}$ ) treatment.

\subsection{Plant Diameter}

Plant diameter was significantly affected by variety. The highest plant diameter $(21.15 \mathrm{~mm})$ was obtained in C-3069 and the lowest plant diameter $(17.70 \mathrm{~mm})$ was found in $\mathrm{C}$ 3473 and C-2197 (Table 1). Plant diameter a significant yield contributing characters of jute was significantly influenced by potassium application. With increasing levels of potassium and also for increasing plant age the base diameter increased gradually. The highest increase in plant diameter $(22.60 \mathrm{~mm})$ was recorded $55 \mathrm{~kg} \mathrm{~K} \mathrm{ha}{ }^{-1}$. The lowest plant diameter was noted at without potassium $\left(\mathrm{K}_{0}\right)$. Similar result was found by [13]. They found highest $(15.5 \mathrm{~mm})$ stick diameter from $0-9897$ and the lowest value $(10.2 \mathrm{~mm})$ in CVL-1. This result supported the result of [1]. The interaction of variety and level of potassium showed a significant effect on plant diameter. The highest plant diameter $(24 \mathrm{~mm})$ was obtained from C-3069 at $55 \mathrm{~kg} \mathrm{~K} \mathrm{ha}^{-1}$ and the lowest $(16.54 \mathrm{~mm})$ was recorded in $\mathrm{C}-2197$ at $0 \mathrm{~kg} \mathrm{~K}$ $\mathrm{ha}^{-1}$, which was statistically similar to $\mathrm{C}-3473$ at $0 \mathrm{~kg} \mathrm{~K} \mathrm{ha}^{-1}$ (17mm) (Table 3).

\subsection{Green Weight with Leaf}

The green weight with leaves exhibited significant response due to variety. The highest green weight with leaves $(4.04 \mathrm{~kg})$ was recorded in C-3473 which was statistically similar to C-2197 (4.03kg) and the lowest $(3.85 \mathrm{~kg})$ C-3069 (Table 1). The variation in green weight with leaves of white jute was significant with respect to level of potassium. The highest green weight with leaves $(4.43 \mathrm{~kg})$ was obtained in $55 \mathrm{~kg} \mathrm{~K} \mathrm{ha}^{-1}$ which was statistically similar to $\mathrm{K}_{35}(4.39 \mathrm{~kg})$ and the lowest $(3.43 \mathrm{~kg})$ was found from control $\left(0 \mathrm{~kg} \mathrm{~K} \mathrm{ha}^{-1}\right)$ but it statistically similar to $45 \mathrm{~kg} \mathrm{~K}(3.61 \mathrm{~kg}$ ) (Table 2). [13] reported that the variation in fresh weight with leaves of Jute plant was significant with respect to levels of $\mathrm{K}$. The highest fresh weight $\left(7.62 \mathrm{t} \mathrm{ha}^{-1}\right)$ was obtained in $30 \mathrm{~kg} \mathrm{~K} \mathrm{ha}^{-1}$ and the lowest weight $\left(3.63 \mathrm{tha}^{-1}\right)$ from $0 \mathrm{~kg} \mathrm{~K} \mathrm{ha}{ }^{-1}$. The interaction of variety and level of potassium had a significant effect on green weight with leaves. The highest green weight with leaf $(4.85 \mathrm{~kg})$ was recorded in variety C-3473 with $55 \mathrm{~kg} \mathrm{~K} \mathrm{ha}^{-1}$ and the lowest $(3.26 \mathrm{~kg})$ was obtained in $\mathrm{C}-3473$ with no potassium application, which in turn statistically similar to C3069 at $45 \mathrm{~kg} \mathrm{~K} \mathrm{ha}^{-1}(3.34 \mathrm{~kg}$ ) respectively (Table 3 ).

\subsection{Green Weight Without Leaf}

The green weight without leaves exhibited significant response due to variety. The highest green weight with leaves $(3.54 \mathrm{~kg})$ was recorded in C-2197 and the lowest was recorded in $(3.41 \mathrm{~kg}) \mathrm{C}-3069$ which was statistically similar to $\mathrm{C}-3473$ (3.46kg) (Table 1). The highest $\left(10.74 \mathrm{t} \mathrm{ha}^{-1}\right)$ weight of fresh stick was obtained from O-9897 and the lowest weight $\left(7.20 \mathrm{t} \mathrm{ha}^{-1)}\right.$ was from CVL 1. This result is well in agreement with the present study. The fresh weight of ten plants exhibited significant response to level of potassium. The highest green weight $(3.91 \mathrm{~kg})$ was obtained 
in $55 \mathrm{~kg} \mathrm{~K} \mathrm{ha}^{-1}$ which was statistically similar to $35 \mathrm{~kg} \mathrm{~K} \mathrm{ha}^{-1}$ $(3.89 \mathrm{~kg})$ and the lowest $(3.04 \mathrm{~kg})$ was obtained at $0 \mathrm{~kg} \mathrm{~K} \mathrm{ha}^{-1}$ which was statistically similar to $45 \mathrm{~kg} \mathrm{~K} \mathrm{ha}^{-1}(3.05 \mathrm{~kg})$ (Table 2). The interaction of variety and level of potassium had a significant effect on green weight of plants without leaves. The highest $(4.25 \mathrm{~kg})$ fresh weight of plant without leaves was recorded in variety $\mathrm{C}-3473$ with $55 \mathrm{~kg} \mathrm{~K}^{-1}$ and the lowest $(2.75 \mathrm{~kg})$ was in $\mathrm{C}-3473$ with $45 \mathrm{~kg} \mathrm{~K} \mathrm{ha}^{-1}$ which was statistically similar to C-3473 with $0 \mathrm{~kg} \mathrm{~K} \mathrm{ha}^{-1}(2.79)$ and C3069 with $45 \mathrm{~kg} \mathrm{~K} \mathrm{ha}^{-1}(2.89 \mathrm{~kg}$ ) (Table 3 ).

\subsection{Fibre Weight Per Plant (g)}

The fibre weight was significantly affected by variety. The highest $(25.92 \mathrm{~g})$ fibre weight of a plant was obtained in variety C-3069, which was statistically similar to C-3473 $(24.42 \mathrm{~g})$ and the lowest was obtained in variety C-2197 (22.95g) (Table 1). The fibre weight exhibited significant response to level potassium. The highest fibre weight (27.93g) plant ${ }^{-1}$ was obtained in $55 \mathrm{~kg} \mathrm{~K} \mathrm{ha}^{-1}$ and the lowest (20.63g) was recorded at $0 \mathrm{~kg} \mathrm{~K} \mathrm{ha}^{-1}$ (Table 2). The interaction of variety and level of potassium showed a significant effect on fibre weight per ten plants. The highest (31g) fibre weight of plant ${ }^{-1}$ was obtained in variety C-3069 with $55 \mathrm{~kg} \mathrm{~K} \mathrm{ha}^{-1}$ and the lowest $(19.67 \mathrm{~g})$ was recorded in variety C-2197 without potassium (Table 3).

\subsection{Fibre Yield ( $\left.\mathrm{ha}^{-1}\right)$}

The fibre yield $\left(\mathrm{t} \mathrm{ha}^{-1}\right)$ was significantly affected by variety. The highest fibre yield $\left(5.18 \mathrm{tha}^{-1}\right)$ was obtained in C-3069 and the lowest on was obtained in C-2197 (4.59t ha $\left.{ }^{1}\right)$. Variety C-3473 was intermediate regarding fibre yield $\left(4.88 \mathrm{t} \mathrm{ha}^{-1}\right)$ (Table 1). [13] Found that the fibre yield was significantly influenced by variety. They reported the highest fiber yield $\left(4.65 \mathrm{t} \mathrm{ha}^{-1}\right)$ was obtained from O-9897 and the lowest $\left(2.23 \mathrm{t} \mathrm{ha}^{-1}\right)$ from CVL-1. The fibre yield $\left(\mathrm{t} \mathrm{ha} \mathrm{h}^{-1}\right)$ exhibited significant response to level of potassium. The highest fibre yield $\left(5.58 \mathrm{t} \mathrm{ha}^{-1}\right)$ was obtained at $55 \mathrm{~kg} \mathrm{~K} \mathrm{ha}^{-1}$. On the other hand, lowest fibre yield was recorded from control treatment $\left(4.13 \mathrm{t} \mathrm{ha}^{-1}\right)$ (Table 2). The findings of the present study is supported by the findings of [10] who recorded significantly higher fibre yield from the plant fertilized with $\mathrm{K}$ fertilizer. The interaction of variety and level of potassium had a significant effect on fibre yield ( $\mathrm{t}$ ha $\left.{ }^{1}\right)$. The highest fibre yield $\left(6.2 \mathrm{t} \mathrm{ha}^{-1}\right)$ was recorded in C-3069 with $55 \mathrm{~kg} \mathrm{~K} \mathrm{ha}^{-1}$ and the lowest in $\mathrm{C}-2197$ with no potassium (3.93 ha $\mathrm{ta}^{-1}$ ) (Table 3).

\subsection{Stick Weight}

The stick weight differed significantly among varieties. The highest stick weight per plant $(64.75 \mathrm{~g})$ was recorded in C-3069 and the lowest was in C-2197 (56.82g) which was statistically similar to C-3473 (56.97) (Table 1). Application of potassium fertilizer affected stick weight significantly. The highest $(69.60 \mathrm{~g})$ stick weight was recorded from the dose $55 \mathrm{~kg} \mathrm{~K} \mathrm{ha}^{-1}$. The lowest stick weight $(48.57 \mathrm{~g})$ was found from control $\left(0 \mathrm{~kg} \mathrm{k} \mathrm{ha}^{-1}\right)$ treatment (Table 2$)$. The Interaction effect of variety and potassium fertilizer varied significantly. The highest stick weight was recorded (77.53g) from the variety C-3069 at $55 \mathrm{~kg} \mathrm{~K} \mathrm{ha}^{-1}$ and the lowest from C-3473 $\times$ $\mathrm{K}_{0}(46.13 \mathrm{~g})$ (Table 3).

\subsection{Stick Yield ( $\left.\mathrm{ha}^{-1}\right)$}

The stick yield was significantly affected by variety. The highest stick yield $\left(12.94 \mathrm{t} \mathrm{ha}^{-1}\right)$ was obtained from C-3069 and the lowest from C-2197 (11.32t ha $\left.\mathrm{ha}^{-1}\right)$ which was statistically similar to $\mathrm{C}-3473\left(11.37 \mathrm{t} \mathrm{ha}^{-1}\right)$ (Table 1). The stick yield was found significant response of potassium. The highest stick yield $\left(13.90 \mathrm{tha}^{-1}\right)$ was recorded at $55 \mathrm{~kg} \mathrm{~K} \mathrm{ha}^{-1}$. Conversely, the lowest stick yield $\left(9.70 \mathrm{tha}^{-1}\right)$ was noted from control $\left(0 \mathrm{~kg} \mathrm{~K} \mathrm{ha}{ }^{-1}\right)$ (Table 2). Significant variation was observed among the combinations of variety and different levels of potassium. The highest stick yield $\left(15.50 \mathrm{tha}^{-1}\right)$ was noted from the variety $\mathrm{C}-3069$ at $55 \mathrm{~kg} \mathrm{~K} \mathrm{ha}^{-1}$, whereas the lowest stick yield was found in C-3473 with no potassium fertilizer $\left(9.22 \mathrm{t} \mathrm{ha}^{-1}\right)$ (Table 3).

\section{Conclusion}

Above observation of the present study, it may be concluded that the variety $\mathrm{C}-3069$ and $55 \mathrm{~kg} \mathrm{~K} \mathrm{ha}^{-1}$ as singly or their interaction were more successful for remarkable production of jute. From the present findings of the study it may be suggested that farmers of out country could cultivate the jute by applying $55 \mathrm{~kg} \mathrm{~K} \mathrm{ha}^{-1}$ for getting the higher growth and greater production of jute fibre under the agro-ecological zone of Patuakhali. The overall results thus indicated that the farmers may be advised for application of $\mathrm{K}$ which are necessary to ensure increased yield and quality of jute. But to assess the optimum requirement of nutrients for commercial jute cultivation, further study should be undertaken on priority basis because the fertility status of Bangladesh soils may vary from place to place or region to region.

Table 1. Effects of variety on deshi jute.

\begin{tabular}{|c|c|c|c|c|c|c|c|c|}
\hline Variety & $\begin{array}{l}\text { Plant } \\
\text { height (m) }\end{array}$ & $\begin{array}{l}\text { No. of } \\
\text { internodes } \\
\text { plant-1 }\end{array}$ & $\begin{array}{l}\text { Plant } \\
\text { diameter } \\
(\mathrm{mm})\end{array}$ & $\begin{array}{l}\text { Green weight } \\
\text { with leaf } \\
\text { (kg plant-10) }\end{array}$ & $\begin{array}{l}\text { Fibre weight } \\
\text { per plant (g) }\end{array}$ & $\begin{array}{l}\text { Fibre } \\
\text { yield } \\
\text { (t ha-1) }\end{array}$ & $\begin{array}{l}\text { Stick weight } \\
\text { per plant (g) }\end{array}$ & $\begin{array}{l}\text { Stick yield } \\
\text { (t ha-1) }\end{array}$ \\
\hline C-3473 & $3.88 \mathrm{a}$ & $63.90 \mathrm{~b}$ & $19.72 \mathrm{~b}$ & $4.04 \mathrm{a}$ & $24.42 \mathrm{~b}$ & $4.88 \mathrm{~b}$ & $56.97 \mathrm{~b}$ & $11.37 \mathrm{~b}$ \\
\hline C-3069 & $3.81 \mathrm{~b}$ & $64.20 \mathrm{a}$ & $21.15 \mathrm{a}$ & $3.85 \mathrm{~b}$ & $25.92 \mathrm{a}$ & $5.18 \mathrm{a}$ & $64.75 \mathrm{a}$ & $12.94 \mathrm{a}$ \\
\hline C-2197 & $3.76 \mathrm{c}$ & $62.80 \mathrm{c}$ & $19.70 \mathrm{~b}$ & $4.02 \mathrm{a}$ & $22.95 \mathrm{c}$ & $4.59 \mathrm{c}$ & $56.82 \mathrm{~b}$ & $11.32 \mathrm{~b}$ \\
\hline Level of significance & $* *$ & $* *$ & $* *$ & $* *$ & $* *$ & $* *$ & $* *$ & $* *$ \\
\hline $\mathrm{CV}(\%)$ & $4.40 \%$ & $3.58 \%$ & $4.02 \%$ & $8.21 \%$ & $6.49 \%$ & $6.52 \%$ & $7.73 \%$ & $7.89 \%$ \\
\hline
\end{tabular}

$* * *=$ Significant at $1 \%$ level of probability. 
Table 2. Effect of different level of Potassium (K) on deshi jute.

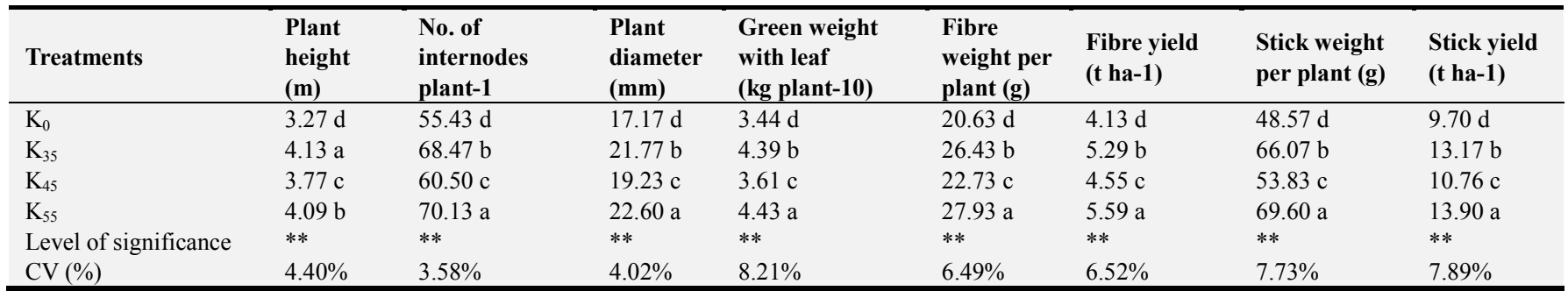

${ }^{* *}=$ Significant at $1 \%$ level of probability.

Table 3. Interaction effect of variety and Potassium (K) on deshi jute.

\begin{tabular}{|c|c|c|c|c|c|c|c|c|}
\hline Variety*Treatments & $\begin{array}{l}\text { Plant height } \\
\text { (m) }\end{array}$ & $\begin{array}{l}\text { No. of } \\
\text { internodes } \\
\text { plant-1 }\end{array}$ & $\begin{array}{l}\text { Plant } \\
\text { diameter } \\
(\mathrm{mm})\end{array}$ & $\begin{array}{l}\text { Green weight } \\
\text { with leaf } \\
\text { (kg plant-10) }\end{array}$ & $\begin{array}{l}\text { Fibre } \\
\text { weight per } \\
\text { plant (g) }\end{array}$ & $\begin{array}{l}\text { Fibre } \\
\text { yield } \\
\text { (t ha-1) }\end{array}$ & $\begin{array}{l}\text { Stick } \\
\text { weight per } \\
\text { plant (g) }\end{array}$ & $\begin{array}{l}\text { Stick yield } \\
\text { (t ha-1) }\end{array}$ \\
\hline $\mathrm{V}_{1} \mathrm{~K}_{0}$ & $3.24 \mathrm{c}$ & $54.73 \mathrm{c}$ & $17 \mathrm{~b}$ & $3.26 \mathrm{c}$ & $20.66 \mathrm{c}$ & $4.13 \mathrm{c}$ & $46.13 \mathrm{c}$ & $9.22 \mathrm{c}$ \\
\hline $\mathrm{V}_{1} \mathrm{~K}_{35}$ & $4.09 \mathrm{ab}$ & $67.66 \mathrm{ab}$ & $20.73 a$ & $4.62 \mathrm{a}$ & $26.2 \mathrm{ab}$ & $5.24 \mathrm{ab}$ & $60.93 \mathrm{ab}$ & $12.18 \mathrm{ab}$ \\
\hline $\mathrm{V}_{1} \mathrm{~K}_{45}$ & $3.9 \mathrm{ab}$ & $60.33 \mathrm{~b}$ & $18.4 \mathrm{ab}$ & $3.44 \mathrm{bc}$ & $21.93 \mathrm{c}$ & $4.38 \mathrm{c}$ & $49.93 \mathrm{c}$ & $9.98 \mathrm{c}$ \\
\hline $\mathrm{V}_{1} \mathrm{~K}_{55}$ & $4.3 \mathrm{a}$ & $73 \mathrm{a}$ & $22.86 \mathrm{a}$ & $4.85 \mathrm{a}$ & $29 \mathrm{a}$ & $5.8 \mathrm{a}$ & $71.06 \mathrm{a}$ & $14.21 \mathrm{a}$ \\
\hline $\mathrm{V}_{2} \mathrm{~K}_{0}$ & $3.32 \mathrm{c}$ & $56.86 \mathrm{c}$ & $18 \mathrm{~b}$ & $3.53 \mathrm{bc}$ & $21.73 \mathrm{c}$ & $4.34 \mathrm{c}$ & $49.4 \mathrm{c}$ & $9.88 \mathrm{c}$ \\
\hline $\mathrm{V}_{2} \mathrm{~K}_{45}$ & $3.68 \mathrm{~b}$ & $61.86 \mathrm{~b}$ & $19.6 \mathrm{ab}$ & $3.34 \mathrm{c}$ & $24 \mathrm{~b}$ & $4.8 \mathrm{~b}$ & $58.13 \mathrm{~b}$ & $11.62 \mathrm{~b}$ \\
\hline $\mathrm{V}_{2} \mathrm{~K}_{55}$ & $4.20 \mathrm{a}$ & $71 \mathrm{a}$ & $24 \mathrm{a}$ & $4.32 \mathrm{ab}$ & $31 \mathrm{a}$ & $6.2 \mathrm{a}$ & $77.53 \mathrm{a}$ & $15.50 \mathrm{a}$ \\
\hline $\mathrm{V}_{3} \mathrm{~K}_{0}$ & $3.26 \mathrm{c}$ & $54.8 \mathrm{c}$ & $16.54 \mathrm{~b}$ & $3.54 \mathrm{bc}$ & $19.67 \mathrm{c}$ & $3.93 \mathrm{c}$ & $50.22 \mathrm{c}$ & $10.04 \mathrm{c}$ \\
\hline $\mathrm{V}_{3} \mathrm{~K}_{35}$ & $4.26 \mathrm{a}$ & $70.6 \mathrm{a}$ & $21.62 \mathrm{a}$ & $4.36 \mathrm{ab}$ & $26.17 \mathrm{ab}$ & $5.23 \mathrm{ab}$ & $63.34 \mathrm{ab}$ & $12.66 \mathrm{ab}$ \\
\hline $\mathrm{V}_{3} \mathrm{~K}_{45}$ & $3.73 \mathrm{~b}$ & $59.46 \mathrm{~b}$ & $19.74 \mathrm{ab}$ & $4.07 \mathrm{~b}$ & $22.34 \mathrm{bc}$ & $4.46 \mathrm{bc}$ & $53.50 \mathrm{bc}$ & $10.70 \mathrm{bc}$ \\
\hline $\mathrm{V}_{3} \mathrm{~K}_{55}$ & $3.79 \mathrm{~b}$ & $66.46 \mathrm{ab}$ & $21.04 \mathrm{a}$ & $4.13 \mathrm{~b}$ & $23.83 \mathrm{~b}$ & $4.76 \mathrm{~b}$ & $60.36 \mathrm{~b}$ & $12.07 \mathrm{~b}$ \\
\hline Level of significance & $*$ & $* *$ & * & $*$ & $* *$ & $* *$ & $* *$ & $* *$ \\
\hline
\end{tabular}

$* *=$ Significant at $5 \%$ level of probability.

[8] Gomez, K. A. and Gomez, A. A. (1984). Statistical Procedures for Agricultural Research. Res. 2nd Edn., John Willey \& Sons, New York. 97-411.

\section{References}

[1] Alam, M. A. K. M., Monjurul, M., Ali, M. A. and Khandaker, S. (1994). Removal of N, P and K from soil by three varieties of Corchorus capsularis L. Bangladesh Jute Res. Inst. Manik Mia Avenue. Dhaka. p. 99.

[2] BBS (Bangladesh Bureau of Statistics). (2012). Statistics Pocket Book of Bangladesh (2010-11). Bangladesh Bureau of Statistics Division, Govt. of the People's Republic of Bangladesh. pp. 91-92.

[3] BJRI (2004a). "Paat Beez Utpadan O Sangrakhan" (A Bangla Booklet on Seed Production of Jute and Storage). Bangladesh Jute Research Institute, Sher-e-Bangla Nagar, Dhaka-1207. P 1.

[4] BJRI (Bangladesh Jute Research Institute) (2008). Annual Report for 2007. Bangladesh Jute Res. Inst, Manik Mia Avenue, Dhaka. p. 127.

[5] Chew, W. Y., M. A. A. Malek and K. Ramli (1982). Nitrogen and potassium fertilization of Congo jute (Urena lobata) and kenaf (Hibiscus canabinus) on Malaysian peat. MARDI-Res. Bulletin. 10 (3): 317-322.

[6] Das, K., Guha, B. and Pathak, D. (1996). Response of capsularis jute to potassium fertilization. Ann. Agril. Res. 17 (2): 188-189.

[7] FAO (2013). Food and Agriculture Organization of United Nations, 2013.
[9] Islam, M. M. (2010). Jute (In Bengali version), Pub. By Dynamic Publisher. Bangladesh. hepzibah on July 24th James (2008, Saluyot (Jute Leaves): The Wow Vegetable (htt://healthmad.com/nutrition/saluyot-jute-leaves-the-wowvegetable).

[10] Maitra, D. N., Ray, P. K., Saha, S., Jana, A. K. and Gangulv, T. K. (2000). Interaction effect of potassium and zinc on the growth and nutrient uptake by jute (Corchorus olitorius L.) in alluvial soil. Agril. Sci. Digest. 20 (2): 75-77.

[11] Sarkar, A. K. and Bandopadhaya (2000). Effect of potassium, boron and crop age on the yield and quality of white jute (Corchorus capsularis L.).

[12] Sarkar, S. K., Ghosh, R. K., Sounda, G., Maitra, S., Rux, D. K. and Ghosh, K. (1997). Effect of levels of nitrogen, potassium and soil moisture tension on growth, nutrient uptake and water use efficiency of jute. Journal of Inter academia. 1 (3): 183-188.

[13] Sarker S. R., Chowdhury, M. A. H., Mohiuddin, K. M., and Saha, B. K., (2012). Influence of different levels of potassium on yield and fibre strength of jute. J. Agrofor. Environ. 6 (1): $39-42$.

[14] Zheng, Z. H., Huang, Y. X, Peng, X. J. and Li, J. L. (1984). Effects of addition K application to jute. China's Fibre Crops, 2: $14-1$. 